\title{
DWARFS AND CRANES. BALTIC-FINNISH MYTHOLOGIES IN EURASIAN AND AMERICAN PERSPECTIVE (70 YEARS AFTER YRJÖ TOIVONEN) ${ }^{1}$
}

\author{
Yuri Berezkin
}

\begin{abstract}
Tales about the struggle between dwarfs and birds are widespread across Eurasia and the Americas. About half of them were known to Toivonen (1937), but a large part of the American and some of the Asian materials remained beyond the scope of his research. The southernmost Eurasian version is from Nagaland. The closest parallels are between Ancient Greek, Fennoscandian, Chinese, Lower Amur and North-American tales. In eastern South America (Upper Xingu) dwarfs at the edge of the earth are replaced with the souls of the dead in the sky. Among 35,000 texts included into the author's electronic database, about 100 Eurasian, North- and South-American cases are relevant to the theme. Several motifs, partially overlapped and variously combined, reflect a unique set of cosmological ideas. Creatures different from (normal) human beings who live in a distant land fight with non-human enemies (birds, crabs, hares, etc.); man readily helps these creatures because for him their enemies are not dangerous; birds attack man who comes to the other world; migratory birds fly from our world to another one; at the boundary, sky is constantly moving in respect to earth or the opening leading to other world is narrow, many birds perish; there is a person at the passage to other world who feeds on birds; mistress of birds lives on the other side of the moving obstacle. The spread of this complex across all the New World allows us to date the corresponding ideas to the time of the initial peopling of the Americas (about 14,000 BP). The complex had taken its final shape in Northern Eurasia. The existence of South American versions and the absence of parallels in Australia and most of South and Southeast Asia (African materials are still not processed) is evidence in favor of historic connections between all known cases. Ecological factors are not sufficient to explain their independent emergence.
\end{abstract}

Key words: peopling of the New World, comparative mythology, Eurasian and Amerindian cosmologies, Yrjö Toivonen

First mentioned by Homer, the legend about pigmies periodically attacked by cranes is repeated by dozens of Greek and Latin authors. The earliest Antique illustration of the story is dated to $570 \mathrm{BC}$ (vase Françoi from Etruria), and this iconographic tradition continues up to about AD 600 well into Byzantine epoch 
(Stahl 1982: 165-182). As long as the study of classical antiquities had been poorly integrated into the mainstream of anthropological research, the Pigmies and cranes motif was considered by many to be peculiar just for the Greeks. In the first third of the 20th century the Finnish school did much to promote the crosscultural study of folklore. Yrjö Toivonen (1890-1956) not only described spectacular Baltoscandian parallels for the antique legend but demonstrated that the Lapp, Finnish and Scandinavian cases are but fragments of a wider areal picture that includes the Siberian and North-American native traditions. Drawing the American folklore to his research, Toivonen used mostly secondary sources, but the series of North-American cases mentioned by him was full enough to make a reliable conclusion about the nature of these distant parallels. The Amerindian myths could not be recently borrowed from the Europeans, and the specific details which they shared with the Eurasian tales could hardly emerge independently. It was highly probable that all this set of motifs had been brought by the ancestors of the American natives from their Asian homeland.

This hypothesis, however, was not elaborated by Toivonen to any extant because a questions of utter importance remained unanswered. How long ago had all these migrations really taken place and for how long could the tales (more precisely, the motifs that define the core of the tales) remain unchanged? The discovery of an extensive series of mythological links across most of the Northern Hemisphere was a puzzle which Finnish school could not resolve in its time. Finnish approach was historic-geographic, i.e. the object of the research was not what the narrator and his audience thought or felt but what were the formal features of the tales and what areal patterns they demonstrated. The existence of similar features inside more or less compact areas opened a possibility to study the nature of historical circumstances responsible for producing the corresponding picture. This approach would be well justified had the folklore data their own chronology (history without chronology is a nonsense). However, from the point of view of their recording, most of the folklore materials are modern. They also lack any inner chronology (unlike linguistics where the knowledge of certain tendencies in phonetic change opens the possibility to date the borrowing from one language into another). As far as we remain inside folkloristics itself, all claims of one feature being more "archaic" than another are based on personal views of particular scholars and cannot be really proven. Nor the mentioning in the texts of cultural phenomena which terminus post quem is approximately known can be a reliable landmark. The evidence suggests that the plot of the story remains unchanged if a buffalo is replaced with a horse and a strong man with a king. 
To be used for the purpose of historical reconstructions, the data of folklore (more precisely, the data on the areal distribution of folklore motifs) should be cross-checked with the materials of populational genetics and especially archaeology, i.e. the disciplines which possess tools for reconstruction of demographic and cultural processes in a real time. A more or less congruent and reliable world-wide picture of prehistory based on archaeological data had been created not before the last quarter of the 20th century. An intensive research on the genetic diversity of the people of the world has begun about the same time. Now, in the early 21 st century, we often forget how overwhelming was the lack of knowledge on prehistory 70 or 80 years ago. In the 1920s Waldemar Bogoras, a colleague of Franz Boas and a great field researcher, was writing about the Eskimo living in the Bering Sea region "in early Quartenary" (Bogoras 1924: 237). Accordingly, up to the 1980s, the historic-geographic approach in folkloristics had to remain sterile. One either reveals the links between traditions but reserves his or her judgment on their historical meaning or one suggests interpretations which could be plausible but are never proven enough to be used as a base for further reconstructions. It is totally logical that in the 20th century the study of the mythology and folklore followed other directions influenced by the development of ideas in cultural anthropology (psychologism, structuralism, functionalism, interpretivism). But just the recent change of the general situation in the research on the human past (achievements in archaeology and populational genetics as well as the development of computer technology) opens the possibility to claim back the legacy of the Finnish school.

This paper is based on the author's Catalogue of the Motifs of World Mythology and Folklore which now (October 2005) contains the data on the distribution of 1,230 motifs selected from more than 35,000 texts. The distribution of motifs is systematically checked though 225 areas of America, Eurasia and Oceania. Africa, Western Europe, the Near East, and most of Polynesia are not still thoroughly examined. Unlike printed indexes of tales and motifs, the electronic database allows the possibility to repeat the abstract of any text as many times as many motifs the text contains. Consequently we can easily follow all the associations of a given motif with others.

Though some of our motifs coincide with the motifs of Stith Thompson's index (Thompson 1955-1958), such a correspondence is to a large degree accidental because the approaches to the selection of motifs are different. Thompson defined the motif as "the smallest element in a tale having a power to persist in tradition" (Thompson 1951: 415). This restriction ("the smallest") was necessary to make the motifs into the appropriate units for the formalized description of texts. In any particular text the number of such elementary motifs is great but restricted. For me, the motif is any image, structure, element of the 
plot or any combination of such elements which could be found at least in two (practically, in many) texts. There is no sense to speak about motifs at all as far as we have only one text, but the potential number of motifs in the world folklore is infinite.

Only small part of this multitude is, however, relevant for any given research. The selection of the applicable motifs depends on the purpose and scale of the research. Our database has been created with the purpose to study demographic and cultural processes which had place in prehistory and defined the global picture of the areal distribution of motifs. The peopling of America and of the Indo-Pacific borderlands of Asia are of prime interest. Accordingly, if we study the less extensive territories and the processes not so remote in time, we should select other sets of relevant motifs.

Pigmies fight cranes is one in a series of thematically related motifs which, partially overlapped and variously combined, fashion a distinct cosmological views. Primitive cosmology is a rather loose complex of ideas and the bearers of a folk tradition are usually unable to describe their cosmology systematically. What they know is but particular tales and ways of interpretation of certain phenomena. It is quite often that some ideas contradict each other to a certain degree. The best way to describe such a cosmology is not to select the "correct" versions from the "aberrant" ones but to review all the pertinent materials.

Below I will give the wording of motifs and the data on their distribution. To save space, I will make no comments on the widely-known Ancient Greek data and reduce the content of stories to details immediately relevant for this research. The motifs in question could be provisionally divided into three groups. The first one directly concerns the story about dwarfs fighting cranes, the second one describes the mythical topography, the last one contains characteristics of certain "sub-human" creatures who live at the edge of the world or lived in the past. Often, though not always, it is these creatures who are engaged in the confrontation with birds.

\section{LIST OF RELEVANT MOTIFS}

GROUP I (Fig. 1). 1. Creatures different from (normal) human beings live in a distant land and fight with non-human enemies (birds, crabs, hares, etc). 2. A man who has come to a distant land easily kills creatures who attack him; usually they are the enemies of the local inhabitants. Not all tales which contain motif 1 also contain motif 2. In the Chukchi and Polar Eskimo tales the man does not help dwellers of other world but only fights himself with the birds who attack him, not dwarfs. 


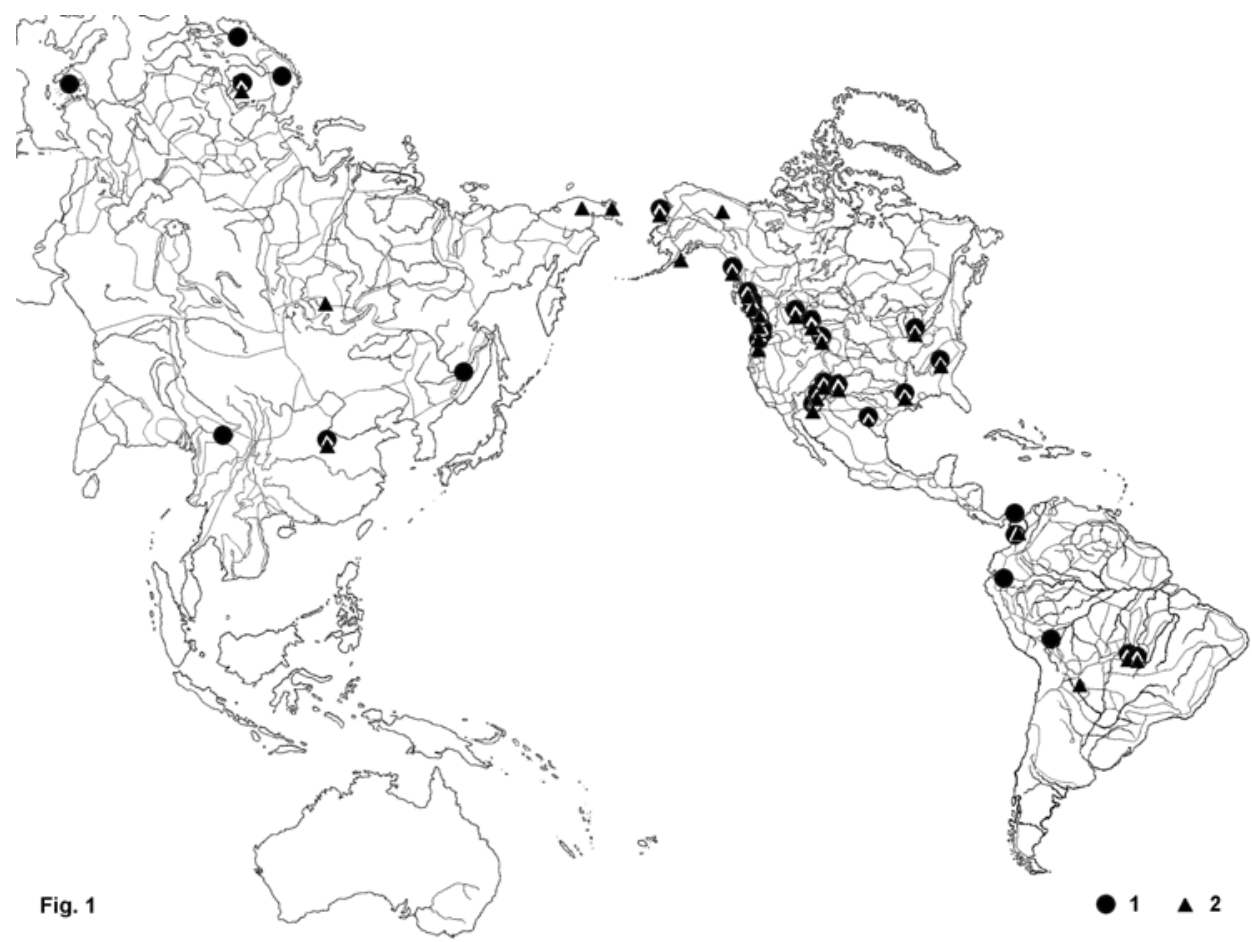

Fig. 1. Dwarfs and cranes.

1. Creatures different from (normal) human beings live in a distant land and fight with non-human enemies (birds, crabs, hares, etc).

2. Man comes to a distant land and easily kills creatures who attack him there (usually they are the enemies of the local inhabitants).

\section{EURASIA}

Finns. 1) Dwarfs fighting cranes live on an island at the edge of the sky, on the southern edge of the Way of Birds (Milky Way). Dwarfs feed on bird eggs. Man gets there and helps the dwarfs. 2) Dwarfs live where the sky meets the earth and is so low that a normal man cannot stand up there. 3) Cranes attacked dwarfs and destroyed most of them. Those that remained fled to the south on the backs of these birds (Napolskikh 1992: 5-6; Toivonen 1937: 91-103).

Lapps. Dwarfs live far to the east in the land of birds (Toivonen 1937: 92).

Ancient China. 1) Cranes attack dwarfs who live beyond the South Sea, giants from adjacent land help the dwarfs. 2) Swans attack dwarfs who live beyond the Western Sea (Yuan Ke 1987: 193-194).

Scandinavia. A drawing published in 1555 represents dwarfs in Greenland who ride half-pony-, half-dog-like animals and fight cranes (Toivonen 1937: 89). 
Nanai (Lower Amur). Dwarfs live beyond the sea. Every year the Chinese emperor sends geese to exterminate them but they repulse the attack (Shimkevich 1897: 137).

\section{NORTHEAST INDIA}

Sema Naga. Flying foxes (i.e., big bats) regularly attack the village of women who live without men (Hutton 1968: 258-259).

\section{ARCTIC}

Chukchi. Man hides the clothes of a bathing Duck- or Gull-girl, marries her. She flies away. He comes to her land, easily kills the birds who attack him, brings his wife back (Baboshina 1958, no. 33: 90-92; Bogoras 1928, no. 48: 429432).

Inupiaq of the Bering Strait. Man gets to see a naked girl, marries her, she proves to be Duck, abandons him. He comes after her to her village. Other ducks attack its inhabitants, the man easily kills the attackers (Jenness 1924, no. 23: 49-52).

Polar Eskimo. Man steals the feather skins of a bathing Goose-girl, marries her. She flies away, he finds her in the Goose land, marries again, she dies. Giant gives him a whip to fight the attacking geese, he kills most of them, the rest fly away (Holtved 1951, no. 36: 55-59).

\section{AMERICAN NORTHWEST COAST}

Tlingit. Man steals the feather skins of two Brant-girls, marries them. They fly away, he comes to the country of birds. Herons attack brants, the man kills many herons, saves the brant tribe, herons and brants make peace. In another version cranes and geese attack brants (Swanton 1909, nos. 24, 54: 55-57, 206208).

Tsimshian. Four men come to the land of dwarfs who fight with ducks, geese, cormorants, blackbirds, cranes, swans. Many dwarfs die of feathers that stuff their noses and mouths. Men easily twist the birds' necks. Thankful dwarfs bring men back to their country (Boas 1902: 108-115).

Bella Coola. Hunter comes to the land of dwarfs. In spring, humming-birds, water fowl and other birds attack them. Hunter easily kills geese and swans, roasts and eats them (McIlwraith 1948: 457-459).

Comox. Men in a boat get to the village of dwarfs. Birds attack dwarfs shooting them with their feathers. Men club the birds, revive dwarfs. Thankful dwarfs send the men back to their home (Boas 1895, no. 16: 87-89). 
Snohomish. Men in a boat come to dwarfs who have tiny mouths and eat only maggots. Dwarfs make war with ducks, snipes, geese. Men kill the birds, cure the wounded dwarfs, return home (Haeberlin 1924, no. 35: 428-430). Similar texts are known to other Coast Salishan groups, in particular to the Skagit (Hilbert 1985: 73-86) and the Nisqually (Boas 1916: 868).

Yakima. Man flies on the back of a giant bird to its nest, lives there. He gets to see a canoe with small people, they take him to their village. Small people breathe through tiny orifices, have no mouths, do not eat but suck wampum beads. Geese and ducks attack them, dwarfs are smothered by feathers of birds sticking to their mouths. Man helps them to win, they give him a wife. When he becomes old, he returns home (Hines 1992, no. 20: 69-76).

\section{MIDWEST AND PLAINS}

Fox. Man gets to dwarfs who cut open their wives to take out the child. He instructs them how to deliver. These people have no anuses, are amazed to see him defecating (he probably makes them anuses, no details). Geese, cranes, brants attack the dwarfs, the man easily kills the birds, cooks the meat (Jones 1907, 5: 75-77).

Blackfoot (many variants). A youth with a scar on his face comes to the Sun. Cranes and other birds have almost exterminated the Sun people. The youth kills the birds, grateful Sun makes him handsome, sends back to earth (Clark 1960: 66-67; 1966: 243-248; Edmonds \& Clark 1989: 228-230; Grinnell 1962: 93-103; Spence 1985: 200-205; Wissler, Duvall 1908, no. 4: 61-66).

Gros Ventre. Two friends come to the giants. Eagles with spears on feet attack giants cutting their veins. Men easily club eagles to death (Kroeber 1907, no. 39: 115-116).

Crow. Hunters follow buffaloes down a cave, come to the giants who use buffaloes for the horses. Their enemies are insects, small birds and animals. Hunters kill birds and animals, grateful giants help to drive buffaloes back to earth (Lowie 1918: 216-218; Simms 1903, no. 14: 295-297).

\section{THE SOUTHEAST}

Natchez. For a race of little people small seems large and vice versa. Normal man visits them. They fight with yellow jackets and cranes, many perish. Man flails yellow jackets with a bush, kills cranes with a club. Dwarfs kill a buffalo, one of them carries it alone (Swanton 1929, no. 19: 247-248).

Cherokee. Young men come to a tribe of dwarfs. Geese and other birds make war upon dwarfs. The men teach them to strike birds on the neck with clubs. 
Later the cranes come. The little men cannot reach up to strike them on the neck, the cranes kill them all (Mooney 1900, no. 74: 325).

\section{GREAT SOUTHWEST}

Zuni. Dwarfs in the underworld feed on steam of food, jays and cooking pots attack and kill them. Twin brothers descend to the underworld, ensnare jays, break pots, cut anuses for the dwarfs, give them to eat (Cushing 1901: 400410).

Southern Athabaskans (Navajo, Jicarilla, Western Apache, Lipan). Youth gets to the sky, helps eagles to kill bumble-bees, wasps, locusts, weeds, pumpkins, gourds, melons (Goddard 1911, no. 18: 211-212; 1918: 67-68; 1919: 132135; Johly, B’yásh 1958: 11; Opler 1938, no. VIIIa: 374-381; 1940, nos. 4-6: 4647; Reichard 1977, no. 4: 26-36; Yuinth-Nezi, Hatráli 1957: 5-6).

\section{LOWER CENTRAL AMERICA AND SOUTH AMERICA}

Cuna (Panama). Man flies with vultures to the east and takes part in the war of birds. Vultures with eagles, doves, pheasants and others fight against pelicans, herons, crows and storks. Man easily kills birds with a stick helping vultures to win, returns home (Wassen 1934, no. 7: 12-15).

Choco (Embera and Nonama, Northwestern Colombia). Man tries to reach the Moon, falls to western horizon, gets into the underworld, meets there people who have no anuses and feed on the odor of food. He kills their dangerous enemies, the crayfish, cuts for some of them anal openings but they die. Sun takes him into his boat, brings back to earth (Isaza Bravo 1987: 128-129; Wassen 1935, no. 8: 133-137).

Shuar (Eastern Ecuador). Sky women first do not like a woman from earth but welcome her when she kills and eats flying ants, their dangerous enemies (Pelizzaro 1993: 188-192).

Tacana (Eastern Bolivia). Man gets to the underworld through the armadillo's hole. Local people are dwarfs, have no anuses, inhale odor of food, tapiti hares are like jaguars for them. Man easily kills tapitis, marries a girl, cuts anal openings for some dwarfs, they die. Man returns to earth (Hissink, Hahn 1961, no. 220: 351-354).

Kuikuru, Kamaiura (Upper Xingu). Man accompanied by his dead friend gets to the sky world of the dead. Ghosts do not like alive person but thank him when he kills birds (eagles, parrots, and others), crayfish, toads who are their dangerous enemies. The man tramples down sharp grasses which are also dangerous for the souls. Fighting the birds the dead men use arrows, women 


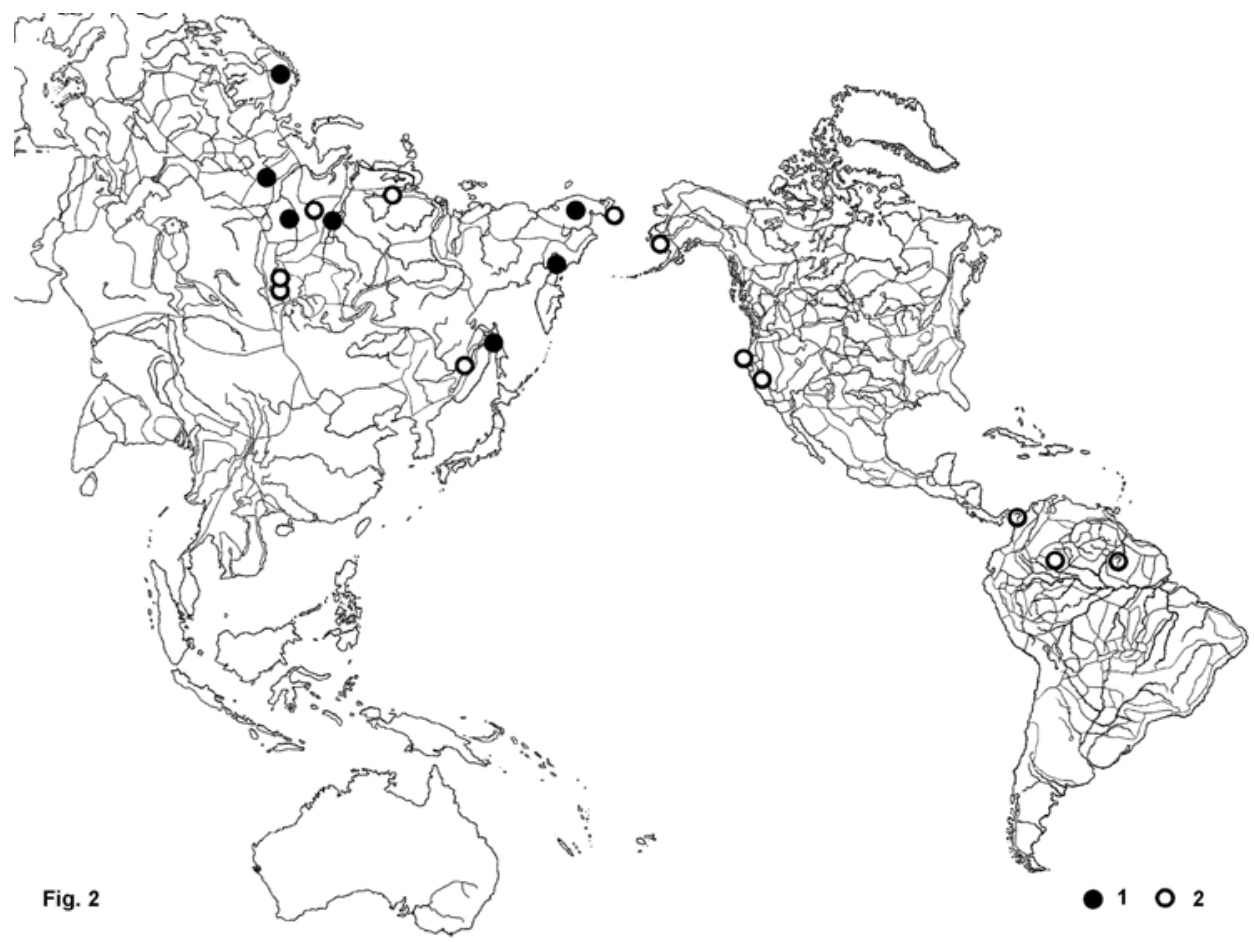

Fig. 2. Birds on the way to another world. All or some of the following motifs are present: migratory birds fly from our world to another one; special bird is their leader; at the boundary many birds perish, because the opening leading to other world is narrow, flanked with clapping rocks, etc; there is a person at the passage to other world who feeds on birds; the mistress of birds lives on the other side of the moving obstacle.

1. Cases considered by Yrjö Toivonen.

2. Additional cases.

use their spindles (Agostinho 1974, no. 10: 200-201; Carneiro 1977: 8-11; Villas Boas, Villas Boas 1973: 127-134).

Nivakle (Chaco). Man comes to the sky where stars and birds live. They are thankful when he kills a rat, because for the bird-people it is a jaguar. Eagle brings him back to earth (Wilbert, Simoneau 1987, nos. 12, 15: 42-49, 59-64).

GROUP II. 3. Migratory birds fly from our world to another one. 4. Special bird is their leader. 5. At the boundary many birds perish, because the opening leading to the other world is narrow, flanked with clapping rocks or the sky itself is constantly moving in respect to earth (Fig. 2). 6. There is a person at the passage to other world who feeds on birds. 7. Mistress of birds lives on the 


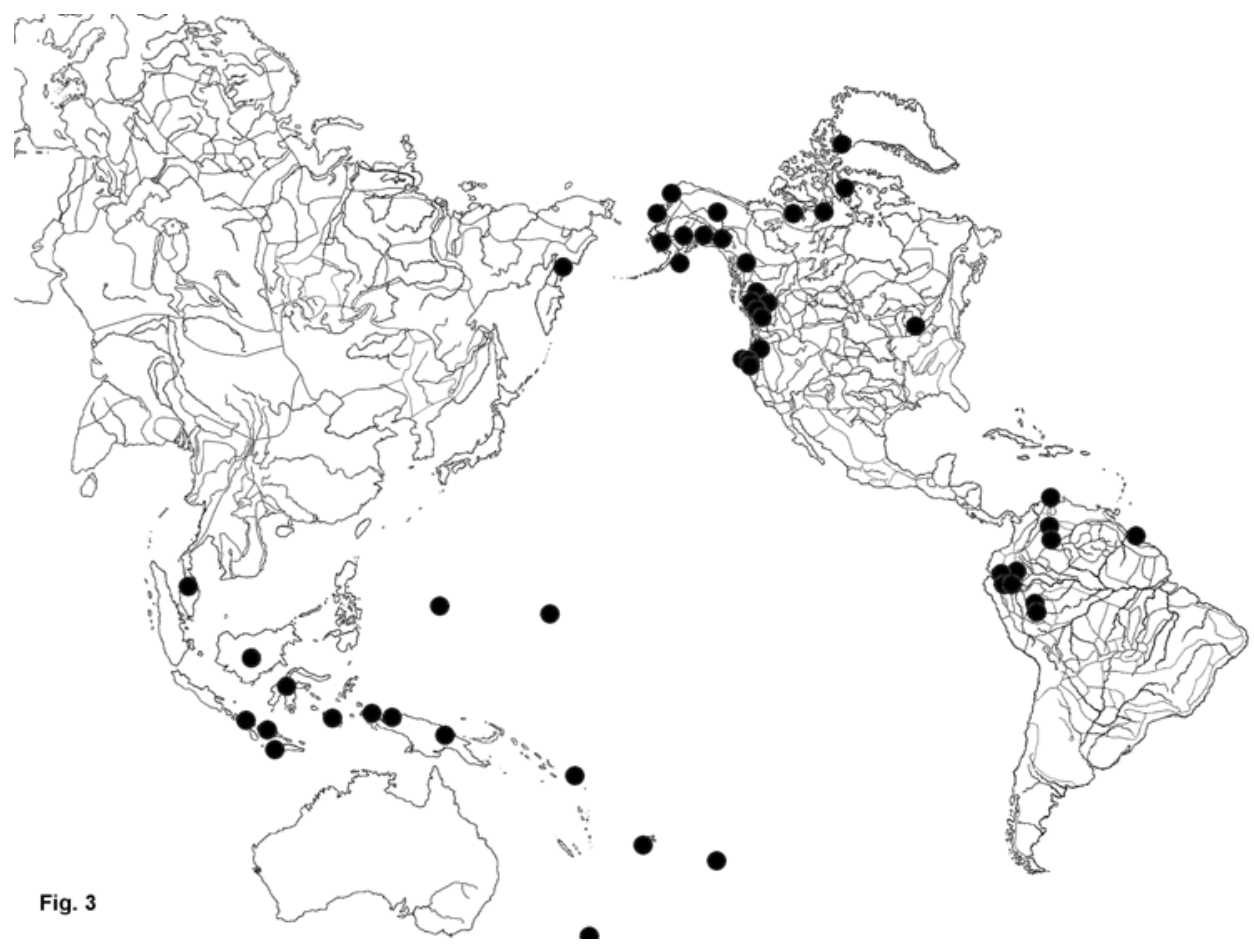

Fig. 3. The abnormal birth. Women were cut open to extract the child, somebody teaches them to deliver properly.

other side of the moving obstacle. 8. Sky is constantly moving in respect to earth (Fig. 3).

\section{BALTOSCANDIA}

Lapps. Every fall migratory birds fly to the birds' land. Little men hunt them there, do not break their bones. The Mistress of Birds sends the birds back to the world (probably reviving them from bones). The crane leads birds to earth, reports to the Mistress how many birds have perished during a year, how many survived (Toivonen 1937: 100-103).

Estonians. Migratory birds fly along the Milky Way (the Way of Birds) led by a swan-like bird with a girl's head. Eagles and hawks are afraid of her. In the summer time she lives on a rock far to the north, birds feed her with delicious berries (Kuperjanov 2003: 151). 


\section{SIBERIA}

Mansi, Hanty. Migratory birds fly to the country beyond the moving edge of the sky. Many birds are crushed, an old man and an old woman feed on them, throw their bones into the water of life, and the birds revive (Karjalainen 1927: 26; Lukina 1990, no. 105: 258-272).

Ket. Migratory birds fly though a narrow opening to the world of the Sun. Some are scorched to death by the sky fire, Tomäm who guards this opening feeds on them (Donner in Toivonen 1937: 108).

Northern Selkup. Old woman from the sky house lives at the source of shamanic rivers. She plucks ducks, throws feathers down to earth, they turn back into birds (Tuchkova 2004: 322-323).

Nenets. The lord of one of the sacred sky countries lives at the Lower Ob' in a hut that has no roofing. Birds that fly over his hut cry and fall dead, heaps of bird bones have been accumulated around (Golovnev 2004: 312-313) .

Dolgan. Shamans turn into geese, fly through the opening in the sky. An old woman who is the hostess of the world sits at the opening, feeds on birds that fly by her (Popov 1937: 55).

Altai. Two clapping rocks crash birds and animals who try to run through the gate of the sky (Surazakov 1982: 113).

Teleut. Sky is rising and falling, heaps of bones of birds and animals crushed by the sky lie at this place (Dyrenkova 1949: 137).

Nanai. Several times a year the Chinese open the gate in the wall to let birds and animals in, a big goose flying first. Once the servant forgot to open the gate, many birds and animals perished (Shimkevich 1897: 137).

Nivx. Sky is constantly rising and falling in respect to earth. Every fall swans fly though the opening, some are crushed, an old woman who lives nearby feeds on them (Kreinovich 1929: 79-80).

\section{ARCTIC}

Chukchi. Sky moves up and down above the four corners of the earth. Migratory birds fly into the opening, those lagging behind are crushed. Wild reindeer and animals with rare fur come from there to our world (Bogoras 1907: 332).

Koryak. Every autumn geese fly to another world though a hole in the sky or between clapping rocks. Any goose who gives a cry at this moment is crushed to death. Mother of Birds lives behind this obstacle (Jochelson in Toivonen 1937: 110-111). 
Asiatic Eskimo. Birds fly between clapping rocks which are covered with blood of the crushed ones (Menovschikov 1985, no. 99: 238-241.

Central Yupic. Migratory birds, geese in particular, fly to the south between clapping mountains, the weak ones are crushed (Gillham 1943: 1-16).

\section{CALIFORNIA}

Yurok. Sky is rising and falling above the ocean producing waves. Geese fly to another world through a round hole (in the firmament) (Waterman 1920: 190191).

Miwok. In spring two thunder-brothers fly with migratory birds to the north through the hole in the sky and return for the winter to produce thunderstorms (Merriam 1993: 173-178).

\section{SOUTH AMERICA}

Barasana (Southeastern Colombia). Once a year all kinds of birds fly to WomanShaman (the creator) through the clapping mountains or scissors-like trap. Herons or ibises give feathers to man, he flies with birds, brings to earth the curare poison (Hugh-Jones 1979, no. 4f-g: 278-282; Torres Laborde 1969: 3145).

Wapishana (Guiana) tale lacks Clapping mountains and Mistress of birds motifs but is similar to Barasana text in many other details (Wirth 1950: 198-199). Variants that did have corresponding motifs have not been possibly recorded.

Paresi (Mato Grosso). Edge of the sky is striking against the earth. Shamans turn into birds, fly through. A man who had recently sex with his wife is crushed (Pereira 1986, no. 13: 231).

The last motif of this group (Rising and falling sky) is known in different context across most of NORTH AMERICA (Kaska, Tahltan, Haida, Coastal Salish, Winnebago, Ottawa, Seneca, Delaware, Mandan, Omaha and Ponca, Shawnee, Yuchi, Cherokee, Chitimacha, Alabama, Koasati, Seminole, Yurok, Chukchansi Yokuts, Hopi). There is another South American case besides Paresi (Chimane of BOLIVIA (Daillant 1995: 164, 170)), one at the PHILIPPINES (Bagobo (Benedict 1913, no.2: 21-23; Raats 1970: 38, 61)) and several cases across SIBERIA, in particular Mansi and Hanty (cited above), Yakut (Alekseev 1982: 682), Tungus (Sangi 1989: 181), Teleut (cited above), Tuvinians (Taube 1994, no. 21: 202-205), Buryat (Gomboyev 1890: 18), Mongol (Potanin 1893: 42-43), Nivx (cited above), Udeghe (Lebedeva a.o.1998, no. 105: 471-473), and Chukchi (cited above). 
GROUP III. Among the four motifs included into this group, the last one (the abnormal birth) is widely distributed in South America and especially in the Austronesian world where it is not linked to the other motifs of the complex under research. The lack of space makes me to omit citing of the sources, which are too numerous.

9. Scorched by the Sun. People who live in the underworld, at the sunrise or sunset (often dwarfs) are scorched by the Sun (red-haired, dark-skinned, etc.) because the Sun goes by at the short distance of them. NORTHEAST INDIA (Lakher, Shan Naga), INDONESIA, PHILIPPINES (Mentawei, Toradja, Solor, Bagobo), ANCIENT GREECE (reports on India), PLAINS, THE SOUTHEAST (Blackfoot, Alabama, Koasati), MESOAMERICA (Totonac, Mazatec, Tzeltal, Tzotzil), SOUTH AMERICA (Yanomami, Locono, Akuriyo, Trio, Cayapa, Tacana, Cayapo, Apinaye).

10. No anus or mouth people. First people or creatures who live in a faraway land have no mouth or anal openings. NEW GUINEA (Porapora, Baruya, Kukukuku), EASTERN INDIA, SOUTHEAST ASIA, TAIWAN (Gadaba, Gond, Kond, Pardhan, Sora, Shan Naga, Khmer, Atayal), ANCIENT GREECE (the motif is present only in reports on India), SIBERIA (Mansi, Nenets, Selkup, Yukaghir, Chukchi), ESKIMO (Central Yupic, North Alaskan Inupiaq, Copper, Netsilik, Iglulik, Polar, Baffin Land), NORTHERN ATHABASKANS (Tanaina, Kutchin, Carrier), Southern NORTHWEST COAST-PLATEAU (Nez Percé, Wasco, Wishram, Yakima, Clacamas, Tillamook, Kalapuya), PLAINS AND MIDWEST (Fox, Blackfoot, Hidatsa, Mandan), CALIFORNIA (Yokuts, Mono), GREAT BASIN (Western and Northern Shoshoni, Ute), GREAT SOUTHWEST (Zuni, Lipan), MESOAMERICA (Huastec, Aztec, San Luis Potocí Nahuat, Ixil, Acatec, Tzeltal, Tzotzil, Cakchiquel, Quiche), PANAMA AND NORTHERN SOUTH AMERICA (Eastern Panama, Embera, Nonama, Kamsa and Ingano, Yabarana, Guayabero, Cuiva, Sanema, Taulipang, Colorado, Cayapa, Secoya, Kofan, Shuar, Yagua, Tucuna), INNER AND SOUTHERN SOUTH AMERICA (Cashibo, Urubu, Shipaya, Juruna, Tacana, Tupari, Paresi, Botocudo, Tehuelche).

11. The steam eaters. People or creatures feed on the odor of food (motif is often linked to the previous one but can exist independently). NEW GUINEA (Saibai, Mawatta), NORTHEAST INDIA, INDONESIA, PHILIPPINES, TAIWAN (Shan Naga, Minahassa, Atayal, Apayao), ANCIENT GREECE (reports on India), SIBERIA (Nenets, Mansi, Hanty, Selkup, Nganasan, Yukaghir), ESKIMO (Central Yupic, Copper), NORTHERN ATHABASKANS (Kutchin, Carrier), Southern NW COAST-PLATEAU (Wasco, Wishram, Tillamook), PLAINS, MIDWEST, NORTHEAST (Mandan, Menomini, Onondaga), CALIFORNIA (Yokuts, Mono, Chumash), GREAT BASIN, GREAT SOUTHWEST, 
NORTHWEST MEXICO (Western Shoshoni, Lipan, Zuni, Tarahumara), MESOAMERICA (Huastec, San Luis Potocy Nahuatl, Tzotzil), LOWER CENTRAL AMERICA, COLOMBIA, ECUADOR (Pech, Eastern Panama, Embera, Nonama, Kamsa and Ingano, Colorado, Secoya, Kofan, Tucuna), BOLIVIA (Tacana), SOUTHERN SOUTH AMERICA (Tehuelche).

12. The abnormal birth (Fig. 4). Women were cut open to extract child, somebody teaches them to deliver properly. NEW GUINEA (Warope, Mejprat, Arapesh), OCEANIA (Yap, Santa Cruz, Maori, Rotuma, Rarotonga, Marshall Islands), MALAYSIA, INDONESIA (Semang, Kayan, Amarasi, Dongo, Toradja, Central Flores), NORTHEAST ASIA, ESKIMO (Alutor, Kodyak, Central Yupic, North Alaskan and Bering Strait Inupiaq, Copper, Netsilik, Iglulik, Polar), NORTHERN ATHABASKANS (Tanaina, Tanana, Upper Tanana, Kutchin, Carrier, Chilcotin, Tahltan), Southern NORTHWEST COAST PLATEAU (Shuswap, Thompson, Lillooet, Klamath), MIDWEST (Fox), CALIFORNIA (Yurok, Karok, Hupa), NORTHERN AND WESTERN SOUTH AMERICA (Guajiro, Cuiva, Sicuani, Locono, Waorani, Shuar, Aguaruna, Urarina?, Sharanahua, Cashinahua).

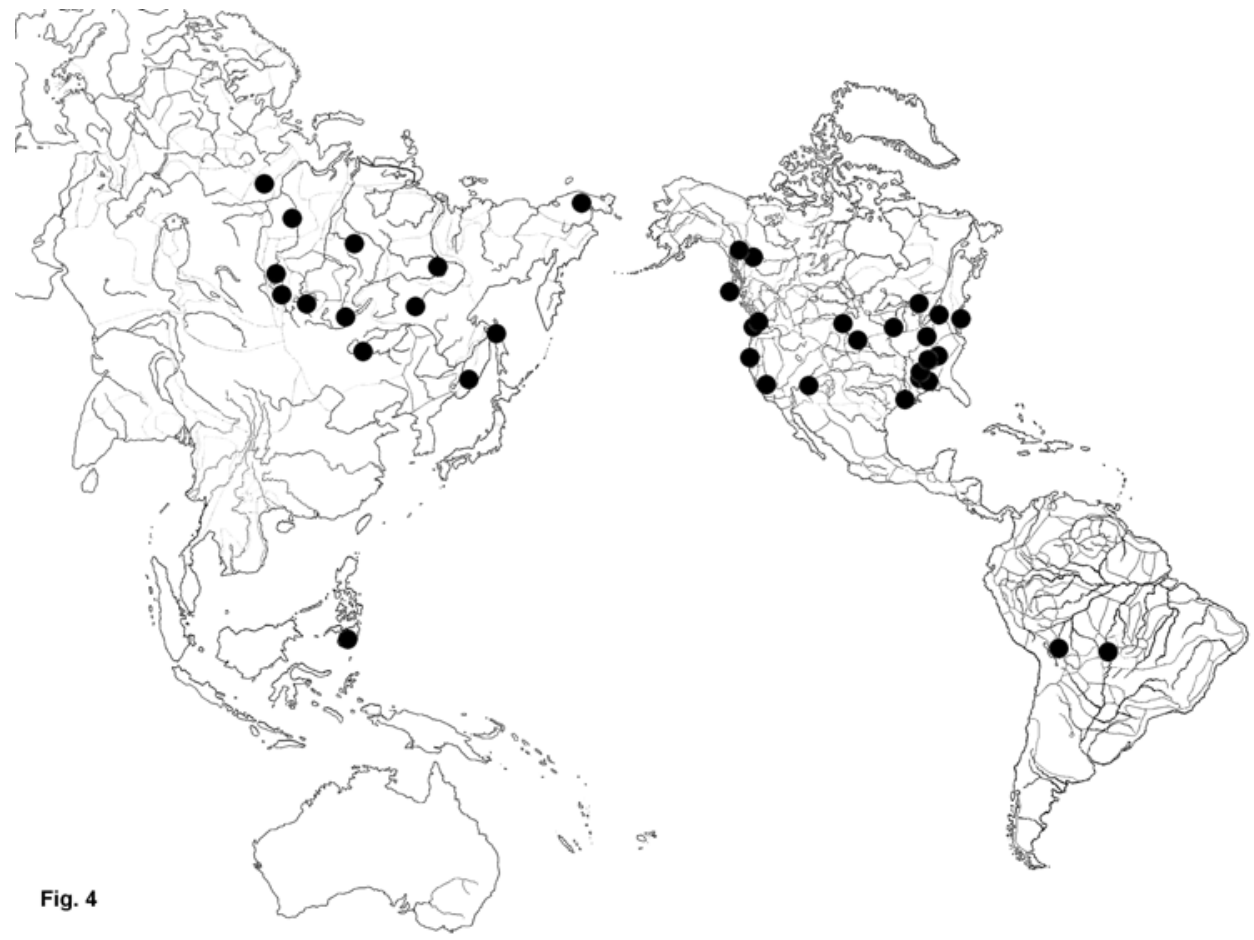

Fig. 4. Rising and Falling Sky. Sky is constantly moving in respect to earth. 


\section{DATING OF DWARFS AND CRANES COMPLEX}

Yrjö Toivonen was aware of more than half of Asian and North-American cases of my Group I but had not investigated the distribution of the motifs which are included here into Groups II and III. South American, East- and SoutheastAsian myths remained beyond the scope of his research. The present widening of geographical frame of the study opens a better opportunity for an approximate dating of the emergence of the set of motifs in question.

The independent emergence of any given motif in different regions is never excluded, but this possibility cannot explain statistical tendencies in areal distribution of the entire complex of motifs. These motifs demonstrate mutual correlation, are widespread across some parts of the Globe and totally absent across other parts. It is difficult to imagine any common ecological, social, or economic factors shared by such completely different areas as Eastern South America, American Arctic, Lower Amur, the Baltics and the eastern Mediterranean. Consequently, such factors could not be responsible for the patterns of the areal distribution of the motifs in question and the only reasonable explanation is the diffusion of the ideas during cultural contacts and their bringing to the new areas by particular groups of people.

The existence of the Dwarfs and cranes and related motifs both in Northern (and to a lesser degree Eastern) Eurasia and in the Americas makes it highly probable that they had been known already at the epoch when the peopling of the New World began. What does it mean in a real time? ${ }^{2}$ Up to the 1980 s the age of the peopling of the New World had remained controversial, dates of about 30-40,000 BP were widely accepted. Since then the situation changed. Though the pre Last Glacial Maximum (LGM, i.e. pre-22000 BP or so) peopling is not completely excluded, the vast majority of archaeologists favor much later dates. Specialists on the populational genetics do believe that the genetic lines which have been found among the American Indians split quite early and the first human groups penetrated the inner regions of the New World (beyond Alaska) before LGM (Oppenheimer 2003: 386-342). However, even if the measurement itself is correct, it does not directly proof the early date for the peopling because the splitting could take place already in Beringia or even in Asia. The same could be said about the great differentiation of the native American (especially South American) languages. Despite many claims of the reverse, no reliable pre-Clovis (10900-11600 BP) sites have been found in the New World. The site of Monte Verde in Chile could be 2,000 years older but the association of artifacts and charcoal samples for radiocarbon analysis is uncertain (Fiedel 1999). There are many arguments against possibility of pre-LGM peopling of the New World (Adams et al. 2001). At the same time, the stone industries of 
the eastern South America do not resemble Clovis. Their creators could possibly enter the New World by the coastal route while the ancestors of the Clovis people most probably were moving along the Yukon and Mackenzie valleys. The existence of the Dwarfs and cranes motif in South America, including the Indians of the Upper Xingu in the very heart of the continent, probably means that the motif was known already to some early migrants.

However, these people were not probably the very first group that had reached the tropical areas of the New World. The thing is that the mythological heritage of the earliest groups who colonized the still uninhabited areas of the New World is expected to be preserved best of all in South America and less well in North America. The latter, being accessible for ever new Asian colonists, was not the best place for preservation of the cultural heritage of the earliest substratum. There is a large set of mythological motifs shared by South-American Indians and by Melanesians, Australians and to some lesser extent by the inhabitants of the Island Southeast Asia but very rare or totally absent both in Siberia and in North America. I can name The shed skin (snakes and other creatures but not humans shed their skin and become young again; Fig. 5) and The wrong call (people are mortal because they answered a call of a being who had brought death or did not hear or answered the call of a being who had

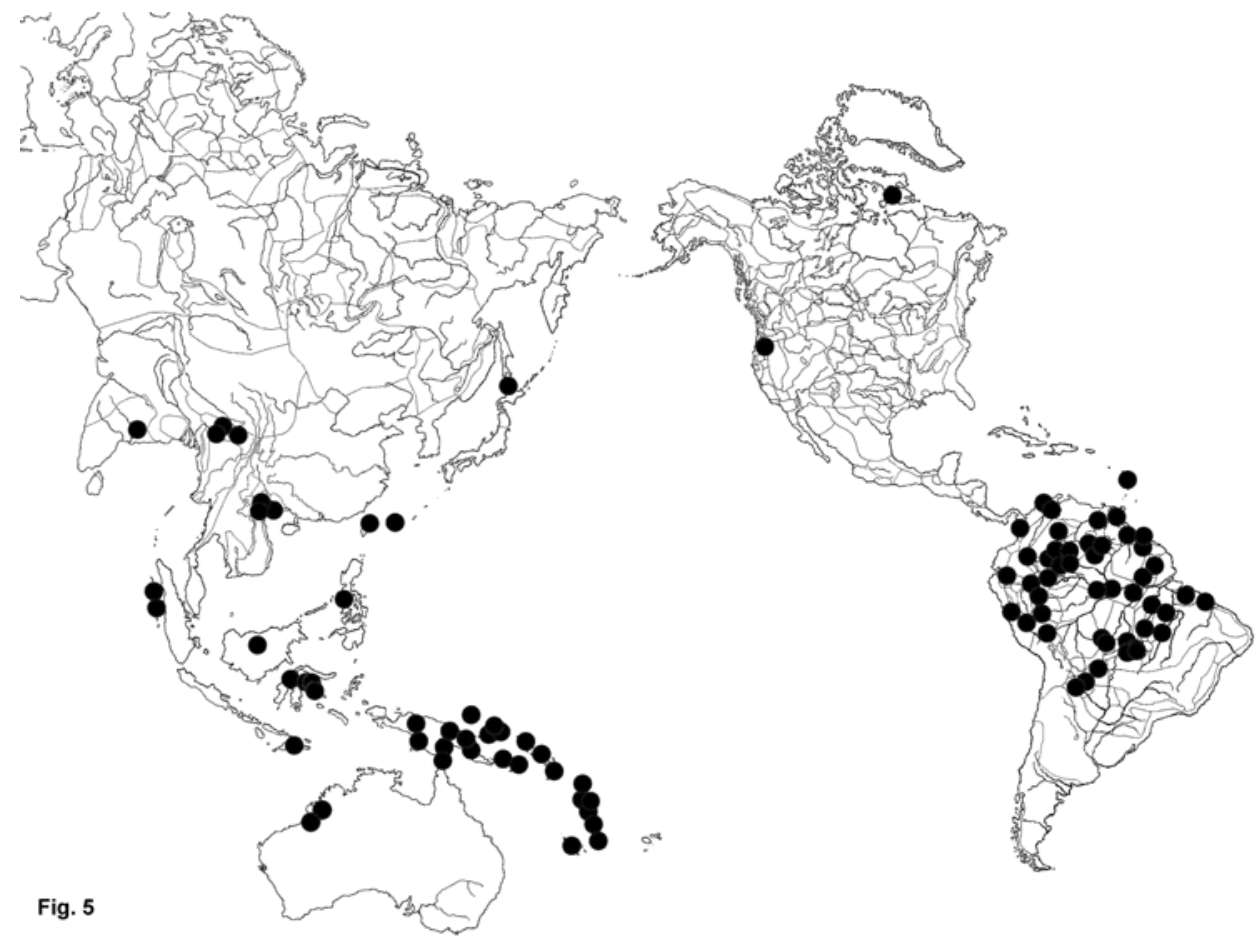

Fig. 5. The shed skin. Those who shed their skin are immortal. 
promised immortality) as typical examples. The regions where such motifs are known are the most unacceptable and far away from the Eurasian mainland and could be considered as the refugia where some culture elements that had disappeared in Asian mainland had opportunity to survive. These motifs do not demonstrate any areal correlation with the Dwarfs and cranes complex which is best represented just in Siberia and North America. The only exception is motif 12 (The abnormal birth) recorded in New Guinea, Micronesia and Indonesia but almost unknown in Northern Asia with the only case among the Koryak (more precisely the Alutor). Both geographically and thematically, The abnormal birth is less directly linked to Dwarfs fighting cranes than other motifs of the complex under consideration.

If the Shed skin and other "South American-Melanesian" motifs could be among the first brought into the New World, there is a quite different complex of motifs which could be the latest to penetrate deep into the American mainland. I mean a set of motifs shared almost exclusively by the North-American

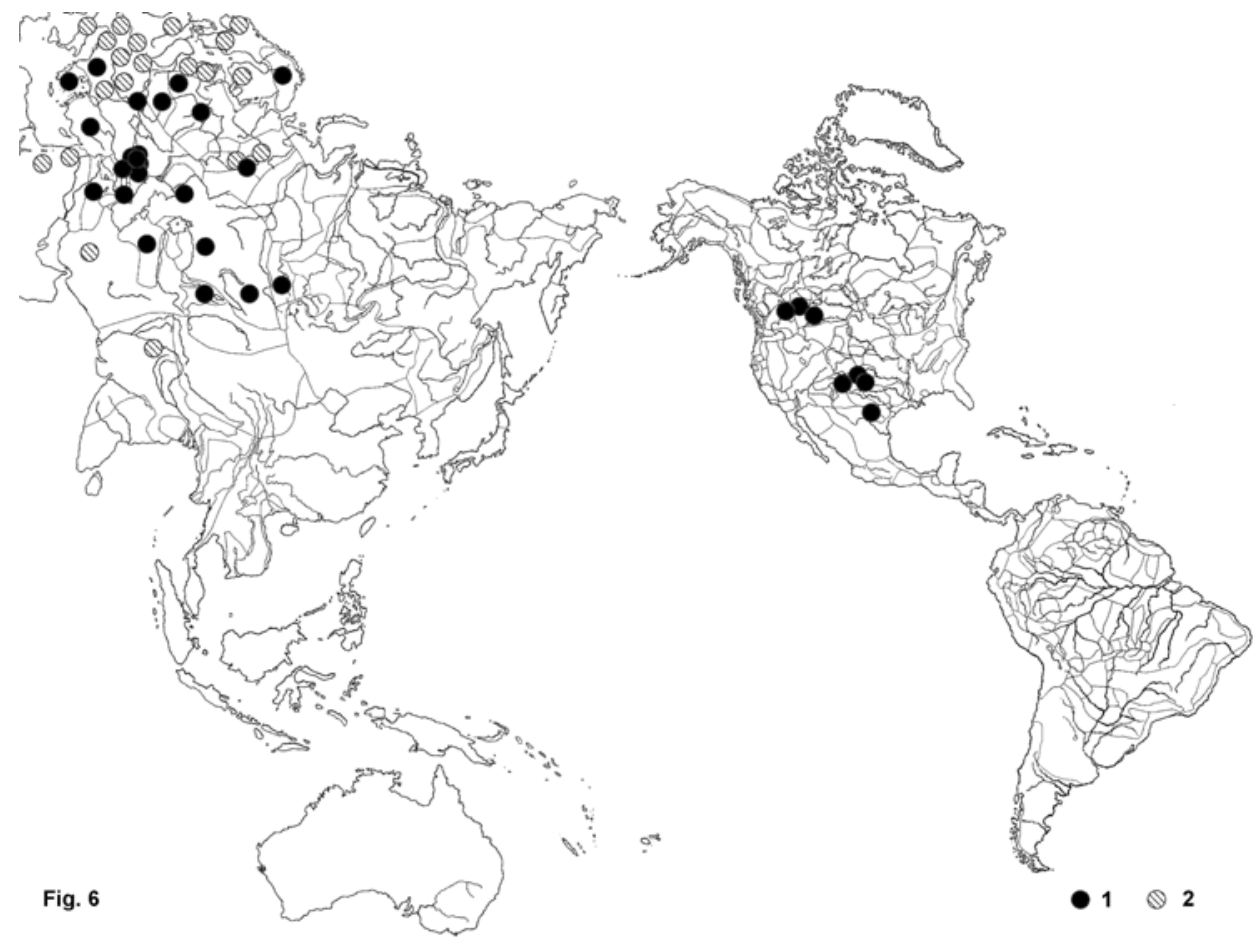

Fig. 6. Escape from Polyphemos' cave. Man gets into dwelling of master of animals or monstrous shepherd, who can kill him.

1. He escapes by covering himself with a sheepskin or by hiding under the belly of one of the animals, who are walking out.

2. Other Polyphemos tales (the episode of hiding under the animal has to be checked). 
Indians to the East of the Rockies and by the people of continental Eurasia, especially those who live between Southern Siberia and the Caucasus (Berezkin $2003 ; 2004)$. An episode of an escape from the cave of the master of animals or monstrous shepherd may serve as an example (Fig. 6).

The Dwarfs and cranes complex stands in between of these two extremes. It is typical of Northern Eurasia and North America, known in South America, though not very widespread there, and unknown in Central Asia, Iran, Xinjiang and Tibet, with a unique case in Assam. Not a single motif of this complex has been found among the Australian aborigines.

We can conclude that the corresponding complex of cosmological ideas had acquired its final shape in Northern Eurasia at the Terminal Pleistocene time and was brought to America by the early but not the very first groups of migrants. To have a definite perspective on the time and circumstances of the development of this system of cosmological ideas, it is necessary to make sure that the motifs in question are absent in Africa. The processing of the African materials is planned for the nearest years. ${ }^{3}$

\section{COMMENTS}

1 The creation of the Catalogue of Myhological Motifs and research on its base have been supported by the Programs of Basic Research of the Presidium of the Russian Academy of Sciences "Ethnocultural interaction in Eurasia" and "Adaptation of peoples and cultures to the environmental changes and to social and technological transformations", by the Russian Fund of Basic Research (grants 04-06-80238 and 0706-00441-a) and by INTAS grant 05-10000008-7922 (a reconstruction of prehistoric Eurasian mythological motif complexes and their most ancient distribution in connection with genetic data").

${ }^{2}$ Absolute dates here are conventional radiocarbon dates. The real calendar dates are about 2,000 years older for $10000 \mathrm{BP}$ and possibly $3,000-4,000$ years older for 20000 BP.

3 Now (September 2007) these materials are largely processed. Though Dwarfs and cranes were known to early Arabian writers, in Africa the corresponding set of motifs seems to be totally absent.

\section{REFERENCES}

Adams, J. M. \& Foote, G. R. \& Otte, M. 2001. Could pre-last glacial maximum humans have existed in North America undetected? An interregional approach to the question. Current Anthropology 42 (4), pp. 563-566.

Agostinho, Pedro 1974. Kwaríp. Mito y ritual no Alto Xingu. São Paulo: Editora Pedagogica e Universitária, Editora da Universidade de São Paulo. 
Alekseev, Nikolai A. 1982. Yakutskaia mifologia [The Yakut mythology]. Mify Narodov Mira, vol. 2. Moscow: Sovetskaia entsiklopedia, pp. 681-682.

Baboshina, Olga E. 1958. Skazki Chukotki [Chukotka Folk-Tales]. Moscow: Gosudarstvennoe izdatelstvo khudozhestvennoi literatury.

Benedict, Laura W. 1913. Bagobo myths. Journal of American Folklore 26 (99), pp. $13-63$.

Berezkin, Yuri E. 2003. Southern Siberian - North American Links in Mythology. Archaeology, Ethnology \& Anthropology of Eurasia 2 (14), pp. 94-105.

Berezkin, Yuri E. 2004. Southern Siberian - North American Links in Mythology. Acta Americana 12 (1), pp. 5-27.

Boas, Franz. 1895. Indianische Sagen von der Nordpazifischen Küste Amerikas. Berlin: Asher.

Boas, Franz. 1902. Tsimshian Texts. Bureau of American Ethnology, Bull. 27. Washington D.C.: Smithsonian Institution.

Boas, Franz. 1916. Tsimshian mythology. 31st Annual Report of the Bureau of American Ethnology, 1909-1910. Washington D.C.: Smithsonian Institution, pp. 291037.

Bogoras, Waldemar 1924. New Problems of ethnographic research in Polar Countries. Proceedings of the 21st International Congress of Americanists, First Part. Leiden: E. J. Brill, pp. 226-246.

Bogoras, Waldemar 1928. Chuckchee tales. Journal of American Folklore 41 (161), pp. 297-452.

Bogoras, Waldemar 1907. The Chukchee. Part 2, Religion. Memoires of the American Museum of Natural History, vol. 11. Leiden \& New York: A. J. Brill \& A. Stechert, pp. 277-536.

Carneiro, Robert L. 1977. The afterworld of the Kuikuru Indians. Colloquia in Anthropology, vol. 1. New Mexico: The Fort Burgwin Research Center, pp. 3-15.

Clark, Ella E. 1960. Indian Legends of Canada. Toronto: McClelland \& Steward.

Clark, Ella E. 1966. Indian Legends from the Northern Rockies. Norman: University of Oklahoma Press.

Cushing, Frank H. 1901. Zuñi Folk Tales. New York \& London: G. P. Putnam, The Knickerbocker Press.

Daillant, Isabelle. 1995. Du fond des Andes au grand aval. L'espace de mythes et l'espace des morts chez les Chimane d'Amazonie Bolivienne. Journal de la Société des Américanistes 81, pp. 159-180.

Dyrenkova, Nadezhda P. 1949. Materialy po shamanstvu u teleutov [Materials on Teleut Shamanism]. Sbornik Muzeia Anthropologii i Etnografii 10, pp. 107-190.

Edmonds, Margot \& Ella E. Clark 1989. Voices of the Winds. Native American Legends. New York, N.Y.: Facts on File, Inc.

Fiedel, S. 1999. Artifact provenience at Monte Verde: confusion and contradictions. Special Report: Monte Verde Revisited. Scientific American Discovering Archaeology 1 (6), pp. 1-12.

Gillham, Charles Edward 1943. Beyond the Clapping Mountains. Esquimo Stories from Alaska. New York: MacMillan.

Goddard, Pliny E. 1911. Jicarilla Apache Texts. Anthropological Papers of the American Museum of Natural History, vol. 8. New York: The American Museum of Natural History. 
Goddard, Pliny E. 1918. Myths and tales from the San Carlos Apache. Anthropological Papers of the American Museum of Natural History 24 (1). New York: The American Museum of Natural History, pp. 3-86.

Goddard, Pliny E. 1919. Myths and tales from the White Mountain Apache. Anthropological Papers of the American Museum of Natural History 24 (2). New York: The American Museum of Natural History, pp. 87-139.

Golovnev, Andrey V. 1995. Govoriaschie kultury. Traditsii samodiitsev i ugrov [Speaking Cultures. Traditions of Samoyed and Ugric People]. Yekaterinburg: UrO RAN, Institut istorii i arkheologii.

Gomboyev, D. G. 1890. Skazania buriat, zapisannye raznymi sobirateliami [The Buryat legends recorded by different collectors]. Zapiski Vostochno-Sibirskogo otdela Imperatorskogo Russkogo geograficheskogo obschestva po etnografii 1: 2. Irkutsk.

Grinnell, George B. 1962. Blackfoot Lodge Tales. The Story of a Prairie People. Lincoln: University of Nebraska Press.

Haeberlin, Hermann 1924. Mythology of Puget Sound. Journal of American Folklore 37 (145-146), pp. 371-438.

Hilbert, Vi (Taqwšeblu) 1985. Haboo. Native American Stories from Puget Sound. Seattle \& London: University of Washington Press.

Hines, Donald M. 1992. Ghost Voices. Yakima Indian Myths, Legends, Humor, and Hunting Stories. Issaquah (Washington): Great Eagle Publishing.

Hissink, Karin \& Hahn, Albert 1961. Die Tacana. Erzälungsgut. Stuttgart: Kohlhammer.

Holtved, Erik 1951. The Polar Eskimos. Language and Folklore. II. Myths and Tales translated by Erik Holtved. Meddelelser om Grønland. Udgivne af Kommissionen for Videnskabelige Undersøglser i Grønland 152: 2. København: C. A. Reitzels Forlag.

Hugh-Jones, Stephen 1979. The Palm and the Pleiades: Initiation and Cosmology in North-West Amazonia. Cambridge a.o.: Cambridge University Press.

Hutton, John H. 1968. The Sema Nagas. London: Oxford University Press.

Isaza Bravo, Antonio 1987. Leyendas y relatos Embera. Relatos y Leyendas Orales: Kamsá - Emberá - Chamí. Bogotá, pp. 107-148.

Jenness, Diamond 1924. Myths and Traditions from Northern Alaska, the Mackenzie Delta and Coronation Gulf. Report of the Canadian Arctic Expedition 1913-1918, vol. 13, part A: Eskimo Folklore. Ottawa: The Kings Printer.

Johly, Hasteen de \& B'yásh, Están Hatráli 1958. Red Ant Myth (Willa-Chee) and Shooting Chant. Recorded and retold in shorter form by Mary C. Wheelwright. Museum of Navajo Ceremonial Art, Bull. 7. Santa Fe, New Mexico: Museum of Navajo Ceremonial Art.

Jones, William 1907. Fox Texts. Publications of the American Ethnological Society, vol. 1. Leyden: E. J. Brill.

Karjalainen, Kustaa F. 1927. Die Religion der Jugra-Völker. Bd. 3. FF Communications 20, no. 63. Porvoo: Suomalainen Tiedeakatemia.

Kreinovich, Yeruhim A. 1929. Ocherk kosmogonicheskih predstavlenii gilyak ostrova Sakhalin [A review of cosmogonic ideas of the Gilyak of Sakhalin Island]. Etnografia 1, pp. 78-102.

Kroeber, Alfred L. 1907. Gros Ventre myths and tales. Anthropological Papers of the American Museum of Natural History 1 (3), pp. 55-139. 
Kuperjanov, Andres 2003. Eesti taevas. Uskumusi ja tõlgendusi [Estonian Sky. Beliefs and Interpretations]. Tartu: Eesti Folkloori Instituut.

Lebedeva, Yelena P. 1998. Fol'klor udegeitsev [The Udeghe Folklore]. Composed and comm. by Ye. P. Lebedeva \& M. M. Khasanova \& V.T. Kialundziugi \& M. D. Simonov. Novosibirsk: Nauka.

Lowie, Robert H. 1918. Myths and Traditions of the Crow Indians. Anthropological Papers of the American Museum of Natural History, 25: 1. New York: University of Nebraska Press.

Lukina, Nadezhda V. 1990. Mify, predania, skazki khantov i mansi [Myths, Legends, Tales of Khanty and Mansi]. Moscow: Nauka.

McIlwraith, Thomas F. 1948. The Bella Coola Indians. Vol. 2. Toronto: University of Toronto Press.

Menovschikov, G. A. 1985. Skazki i mify eskimosov Sibiri, Aliaski, Kanady i Grenlandii [Eskimo Myths and Tales from Siberia, Alaska, Canada, and Greenland]. Moscow: Nauka.

Merriam, C. Hart 1993. The Dawn of the World. Myths and Tales of the Miwok Indians of California. Lincoln \& London: University of Nebraska Press.

Mooney, James 1900. Myths of the Cherokee. 19th Annual Report of the Bureau of Ethnology, 1897-1898, part 1. Washington D.C.: Smithsonian Institution.

Napolskikh, Vladimir V. 1992. Proto-uralic world picture: a reconstruction. Hoppál, M. \& Pentikäinen, J. (eds.) Northern Religions and Shamanism. Ethnologica Uralica 3. Budapest \& Helsinki: Akadémiai Kiadó, Finnish Literature Society, pp. 3-20.

Opler, Morris E. 1938. Myths and Tales of the Jicarilla Apache Indians. Memoires of the American Folklore Society 31. New York: The American Folk-Lore Society, G. E. Stechert.

Opler, Morris E. 1940. Myths and Legends of the Lipan Apache Indians. Memoires of the American Folklore Society 36. New York: American Folk-Lore Society, J. J. Augustin.

Oppenheimer, Stephen 2003. The Real Eve. Modern Man's Journey Out of Africa. New York: Carrol \& Graf.

Pelizzaro, Siro 1993. Shuar. Quito: Abya-Yala.

Pereira, Adalberto H. 1986. O Pensamento mítico do Paresí. Primera parte. Pesquisas, Antropologia 41. São Leopoldo.

Popov, Andrey A. 1937. Dolganski fol'klor [The Dolgan Folklore]. Moscow \& Leningrad: Sovetski Pisatel.

Potanin, Grigori N. 1893. Tangutsko-tibetskaya okraina Kitaya i Tsentralnaia Mongolia [The Tangut - Tibet Borderland of China and Central Mongolia]. Vol. 2. St. Petersburg: Tipografia A.S. Suvorina.

Raats, Pieter J. 1970. A structural study of Bagobo myths and rites. Asian Folklore Studies 29, pp. 1-131.

Reichard, Gladys A. 1977. Navajo Medicine Man Sandpaintings. New York: Dover Publications.

Sangi, Vladimir M. 1989. Antologia fol'klora narodov Sibiri, Severa i Dal'nego Vostoka [Anthology of the Folklore of the People of Sibiria, the North and the Far East]. Krasnoyarsk: Krasnoyarskoe knizhnoe izdatel'stvo.

Shimkevich, P. P. 1897. Obychai, poveria i predania gol'dov [Customs, believes and traditions of the Golds]. Etnograficheskoe obozrenie 33 (3), pp. 135-147. 
Simms, Stephen Ch. 1903. Traditions of the Crow. Field Columbian Museum, Publication 85, Anthropological Series, vol. 2, no. 6, pp. 281-324.

Spence, Lewis. 1985. North American Indians. A facsimile of the original edition (Edinburgh \& London 1914). New York: Avenel Books.

Stahl (Shtaal), Irina V. 1982. Epicheskie predania Drevnei Gretsii. Geranomakhia [Epic Legends of Ancient Greece. Geranomachia]. Moscow: Nauka.

Surazakov, Sazon S. 1982. Iz glubiny vekov [From the Depth of Time]. Gorno-Altaisk: Altaiskoe knizhnoe izdatelstvo.

Swanton, John R. 1909. Tlingit Myths and Texts. Bureau of American Ethnology, Bull. 39. Washington D.C.: Smithsonian Institution.

Swanton, John R. 1929. Myths and Tales of the Southeastern Indians. Bureau of American Ethnology, Bull. 88. Washington D.C.: Smithsonian Institution.

Taube, Erika. 1994. Skazki i predania altaiskih tuvintsev [Tales and Legends of Tuvinians of Altai]. Moscow: Vostochnaia literatura.

Thompson, Stith. 1951. The Folklore. New York: The Dryden Press.

Thompson, Stith. 1955-1958. Motif-index of folk-literature; a classification of narrative elements in folktales, ballads, myths, fables, mediaeval romances, exempla, fabliaux, jest-books, and local legends. 1-6. Bloomington: Indiana University Press.

Toivonen, Yryö H. 1937. Pygmäen und Zugvögel. Alte kosmologische Vorstellungen. Finnisch-Ugrische Forschungen 24 (1-3), pp. 87-126.

Torres Laborde, Alfonso 1969. Mito y Cultura entre los Barasana, un Grupo Indígena Tukano del Vaupés. Bogotá: Universidad de los Andes.

Tuchkova, N.A. 2004. Mifologia Sel'kupov [Selkup Mythology]. Tomsk: Izdatel'stvo Tomskogo universiteta.

Villas Boas, Orlando \& Villas Boas, Claudio 1973. Xingu: The Indians, their Myths. Trans. by Susana Hertelendy Rudge. New York: Farrar.

Wassen, Henry 1934. Mitos y cuentos de los Indios Cunas. Journal de la Société des Américanistes 26 (1), pp. 1-35.

Wassen, Henry 1935. Notes on Southern groups of Chocó Indians in Colombia. Etnografiska Studier 1, pp. 35-182.

Waterman, Thomas T. 1920. Yurok geography. University of California Publications in American Archaeology and Ethnology 16 (5), pp. 177-314.

Wilbert, Johannes, \& Simoneau, Karin 1987. Folk Literature of the Nivaklé Indians. UCLA Latin American Studies 66. Los Angeles: UCLA Latin American Center Publications, University of California.

Wirth, D. Mauro 1950. Lendas dos Indios Vapidiana. Revista do Museu Paulista 4, pp. 165-216.

Wissler, Clark \& Duvall, D. C. 1908. Mythology of the Blackfoot Indians. Anthropological Papers of the American Museum of Natural History. Vol. 2, Part 1. New York: American Museum of Natural History.

Yuan Ke 1987. Mify drevnego Kitaya [Myths of Ancient China]. Moscow: Nauka.

Yuinth-Nezi \& Yoh Hatráli 1957. Myths of the Sóntso and Má-ih (Big Star and Coyote Chants). Museum of Navajo Ceremonial Art, Bulletin 2. Santa Fe, New Mexico: Museum of Navajo Ceremonial Art. 